\title{
Effect of Adding Scoria as Cement Replacement on Durability-Related Properties
}

\author{
Aref Mohamad al-Swaidani ${ }^{1), *}$, and Samira Dib Aliyan ${ }^{2)}$
}

(Received May 5, 2014, Accepted April 14, 2015, Published online May 15, 2015)

\begin{abstract}
A lot of reinforced concrete (RC) structures in Syria went out of service after a few years of construction. This was mainly due to reinforcement corrosion or chemical attack on concrete. The use of blended cements is growing rapidly in the construction industry due to economical, ecological and technical benefits. Syria is relatively rich in scoria. In the study, mortar/concrete specimens were produced with seven types of cement: one plain Portland cement (control) and six blended cements with replacement levels ranging from 10 to $35 \%$. Rapid chloride penetration test was carried in accordance with ASTM C 1202 after two curing times of 28 and 90 days. The effect on the resistance of concrete against damage caused by corrosion of the embedded steel has been investigated using an accelerated corrosion test by impressing a constant anodic potential. The variation of current with time and time to failure of RC specimens were determined at 28 and 90 days curing. In addition, effects of aggressive acidic environments on mortars were investigated through 100 days of exposure to $5 \% \mathrm{H}_{2} \mathrm{SO}_{4}, 10 \% \mathrm{HCl}_{1} \% \mathrm{HNO}_{3}$ and $10 \% \mathrm{CH}_{3} \mathrm{COOH}$ solutions. Evaluation of sulfate resistance of mortars was also performed by immersing in $5 \% \mathrm{Na}_{2} \mathrm{SO}_{4}$ solution for 52 weeks. Test results reveal that the resistance to chloride penetration of concrete improves substantially with the increase of replacement level, and the concretes containing scoria based-blended cements, especially CEM II/B-P, exhibited corrosion initiation periods several times longer than the control mix. Further, an increase in scoria addition improves the acid resistance of mortar, especially in the early days of exposure, whereas after a long period of continuous exposure all specimens show the same behavior against the acid attack. According to results of sulfate resistance, CEM II/B-P can be used instead of SRPC in sulfate-bearing environments.
\end{abstract}

Keywords: durability, corrosion resistance, blended cement, natural pozzolans, acid attack, scoria, sulfate attack.

\section{Introduction}

Use of natural pozzolan in production of blended Portland cements makes important effects on physical, chemical, mechanical and durability properties of mortar and concrete depending on its substitution ratio and its fineness (Al-Chaar et al. 2013; Senhadji et al. 2012; Hossain 2009; Ghrici et al. 2006; Cavdar and Yetgin 2007; Turanli et al. 2005; Colak 2003; Rodriguez-Camacho and Uribe-Afif 2002). In addition, since these materials enter the cement production after kiln process, they also provide important economical and ecological benefits (Mehta and Monteiro 2006). According to Mehta and Monteiro (2006), the manufacture of one tonne of Portland cement (PC) clinker consumes energy of about

\footnotetext{
${ }^{1)}$ Faculty of Architectural Engineering, Arab International University (AIU), Damascus, Syria.

*Corresponding Author; E-mail: aydlswaidani@yahoo.fr; a-swaidani@aiu.edu.sy

${ }^{2)}$ Syrian Arab Organization for Standardization and Metrology (SASMO), Damascus, Syria.

Copyright $($ The Author(s) 2015. This article is published with open access at Springerlink.com
}

4GJ, and releases nearly one tonne of $\mathrm{CO}_{2}$ in the atmosphere. For this reason, a particular attention was recently given to the exploitation of natural pozzolan which is broadly abundant in Syria. More than $30,000 \mathrm{~km}^{2}$ of the country is covered by Tertiary and Quaternary-age volcanic rocks (GEGMR 2011), among which scoria occupies important volume with estimated reserves of more than 600 million tonnes (GEGMR 2007). The cement produced in the country is almost of CEM I, although an addition of natural pozzolan up to $5 \%$ was frequently used in most local cement plants. Hence, less than 300,000 tonnes of these pozzolans are only exploited annually (the annual production of PC in Syria is about 6 million tonnes) (GOCBM 2011).

The premature deterioration of reinforced concrete (RC) structures due to corrosion is a major problem in Syria, especially, in the marine environment. A lot of structures went out of service after a few years of construction. Although chloride ions in concrete do not directly cause severe damage to the concrete, they contribute to the corrosion of steel bars embedded in concrete. Therefore, study of chloride penetrability of concrete is an important for evaluating reinforcing steel corrosion in RC structures. In addition, chemical attacks on concrete structures subjected to sulfate- and acid-bearing environments have caused serious damage to these concretes. This has prompted the search for 


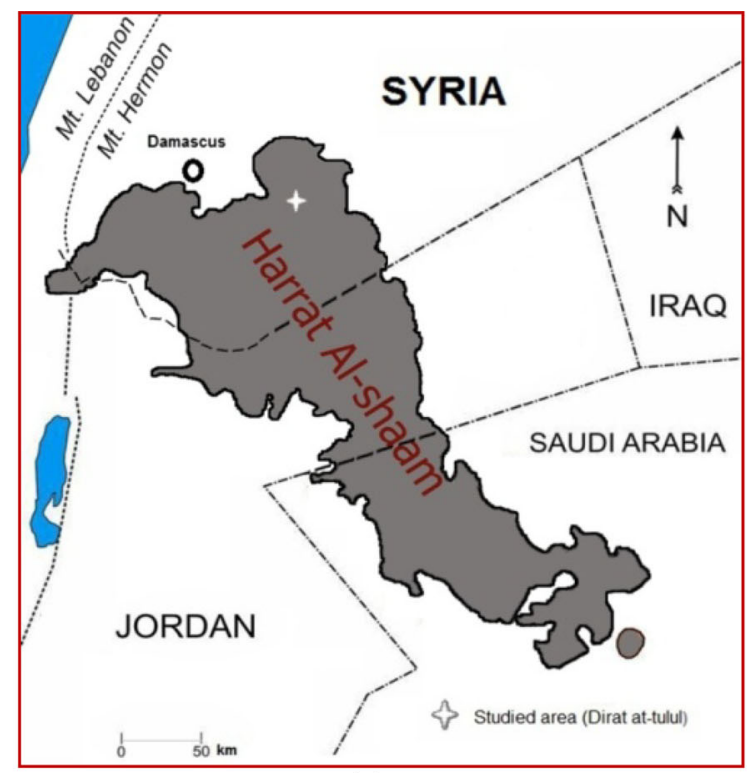

(a)

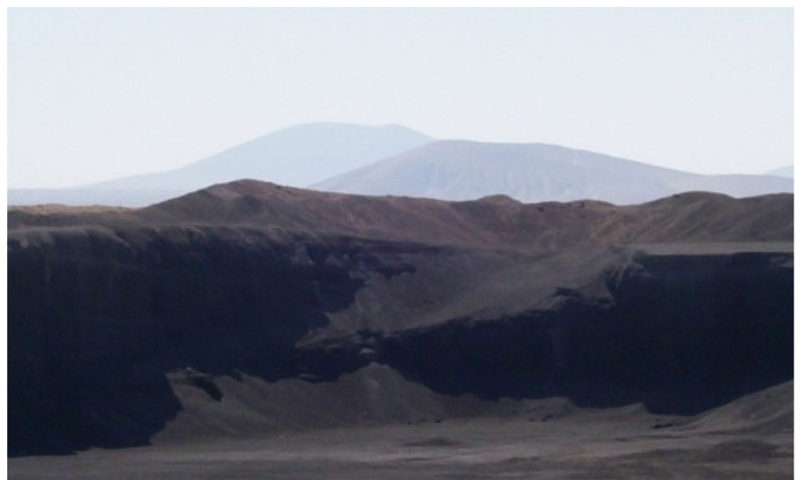

(b)

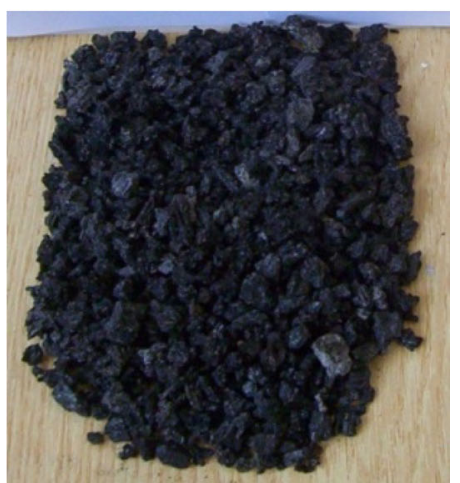

(c)

Fig. 1 Map of Harrat Al-Shaam, photo of the studied quarry \& the used scoria aggregate. a Map of Harrat Al-Shaam and the studied area. b The studied scoria quarry, some volcanic scoria cones are shown behind. $\mathbf{c}$ The studied scoria aggregate.

economical methods of extending the service life of structure. One of these methods was the use of blended cements, which is growing rapidly in the construction industry. Although there are numerous studies on using natural pozzolan as cement replacement, no detailed research was conducted in the past to investigate the potential use of scoria in production of blended cements in Syria.

This study is part of the first detailed research in Syria to investigate the potential utilization of scoria as cement replacement in producing Portland-pozzolan cements, and its effects on the performance of mortar and concrete. The study is of particular importance not only for the country but also for other areas of similar geology, e.g. Harrat Al-Shaam, a volcanic field covering a total area of some $40,000 \mathrm{~km}^{2}$, third of which is located in the country. The rest is covering parts from Jordan and Saudi Arabia.

The objective of this paper is to report a part of this ongoing research on the effect of different amount of scoria when adding as cement replacement on some durability-related properties. Penetrability of chloride ions, corrosion of reinforcing steel, acid and sulfate attacks have been particularly investigated. Some chemical, physical and mechanical properties have also been reported.

\section{Experimental Procedure}

\subsection{Scoria}

The scoria used in the experiments was collected from a Tal Dakwa' quarry, at $70 \mathrm{~km}$ southeast of Damascus as shown in Fig. 1. The petrographical examination showed the scoria is consisted of amorphous glassy ground mass, vesicles, plagioclase and olivine with the following percentages (based on an optical estimate): 20, 35, 20 and $25 \%$, respectively. The scoria is dark black to blackish-grey in color with some red-brown spots, mostly due to its iron oxides content. Figure 2 shows thin sections of the used scoria. The chemical analysis of scoria used in the study is summarized in Table 1. This analysis was carried out by means of wet chemical analysis specified in EN 196-2 (1989).

\subsection{Cement Samples}

Three types of binder were prepared, one plain PC CEM I (control), and two blended cements: CEM II/A-P and CEM II/B-P (EN 197-1), each of them with 3 replacement levels of scoria: $(10,15$ and $20 \%)$ and $(25,30,35 \%)$, respectively. $5 \%$ of gypsum was added to all these cements. The clinker used for producing the binders was obtained from 


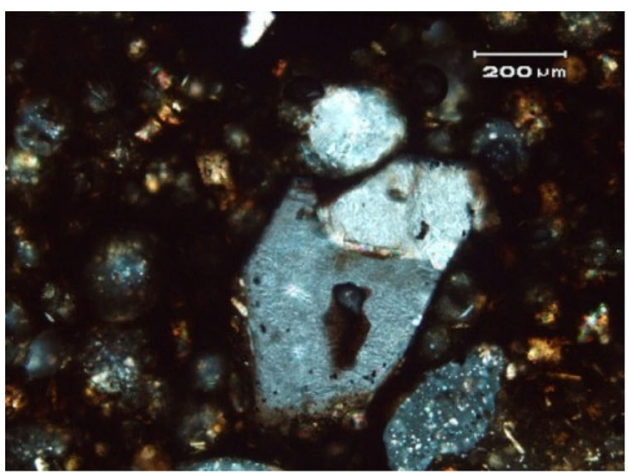

(a)

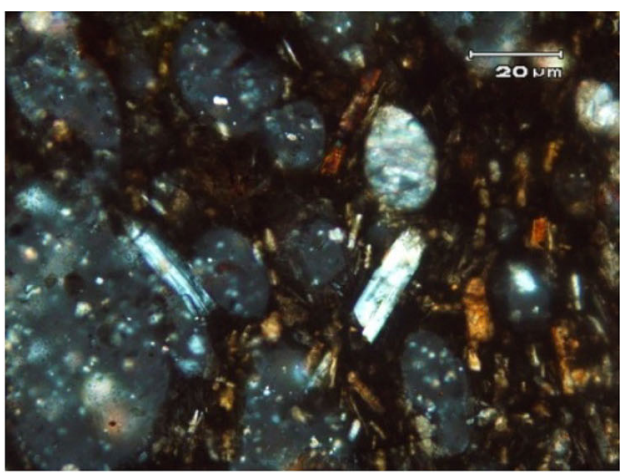

(b)

Fig. 2 Thin sections of the scoria. a Microphenocryst of olivine in volcanic glass matrix with vesicles, some of which are filled with white minerals. b Microphenocrysts of elongated plagioclase in volcanic glass matrix with vesicles, some of which are filled with white minerals.

Table 1 Chemical composition of the used materials.

\begin{tabular}{|c|c|c|c|c|c|}
\hline \multirow{2}{*}{$\begin{array}{c}\text { Chemical composition } \\
\text { (by mass, \%) }\end{array}$} & \multicolumn{3}{|c|}{ Materials } & \multirow[b]{2}{*}{ Dolomite aggregate } & \multirow[b]{2}{*}{ Natural sand } \\
\hline & Scoria $^{\mathrm{a}}$ & Clinker & Gypsum & & \\
\hline $\mathrm{SiO}_{2}$ & 46.52 & 21.30 & 0.90 & 0.42 & 93.39 \\
\hline $\mathrm{Al}_{2} \mathrm{O}_{3}$ & 13.00 & 4.84 & 0.07 & 0.38 & 0.57 \\
\hline $\mathrm{Fe}_{2} \mathrm{O}_{3}$ & 11.40 & 3.99 & 0.10 & 0.10 & 0.24 \\
\hline $\mathrm{CaO}$ & 10.10 & 65.05 & 32.23 & 31.40 & 1.70 \\
\hline $\mathrm{CaO}_{\mathrm{f}}$ & - & 2.1 & - & - & - \\
\hline $\mathrm{MgO}$ & 9.11 & 1.81 & 0.20 & 20.46 & 0.20 \\
\hline $\mathrm{SO}_{3}$ & 0.27 & 0.25 & 45.29 & 0.18 & 1.15 \\
\hline Loss on ignition & 2.58 & - & 21.15 & 46.48 & 2.52 \\
\hline $\mathrm{Na}_{2} \mathrm{O}$ & 2.14 & 0.60 & - & 0.06 & 0.06 \\
\hline $\mathrm{K}_{2} \mathrm{O}$ & 0.77 & 0.28 & - & 0.30 & 0.05 \\
\hline $\mathrm{Cl}^{-}$ & $<0.1$ & 0.05 & - & 0.021 & 0.017 \\
\hline $\begin{array}{c}\text { Pozzolan activity index } \\
\text { [ASTM C 618] }\end{array}$ & $\begin{array}{l}79 \text { (at } 7 \text { days) } \\
85 \text { (at } 28 \text { days) }\end{array}$ & & & & \\
\hline
\end{tabular}

${ }^{\mathrm{a}} \mathrm{SiO}_{2 \text { (reactive) }}$ content in the studied scoria $=42.22 \%$ (determined in accordance with EN 196-2).

Adra Cement Plant, Damascus, Syria. Chemical analysis of clinker and gypsum is shown in Table 1. All binders were interground by a laboratory grinding mill to a Blaine fineness $3200 \pm 50 \mathrm{~cm}^{2} / \mathrm{g}$. All replacements were made by mass of cement. Table 2 shows the chemical, physical and mechanical properties of the binders produced. CEM I (the control sample) was designated as $\mathrm{C} 1$, whereas blended cements were designated according to the replacement level. For instance, $\mathrm{C} 2 / 10 \%$ and $\mathrm{C} 7 / 35 \%$ refer to the blended cements containing 10 and $35 \%$ of scoria, respectively. In acid and sulfate attack tests, sulfate-resisting PC was employed for comparison. It was designated as C8.

\subsection{Mortar Mixtures}

Eight mortar mixtures were prepared using these binders and sand meeting the requirements of ASTM C 778. In all mixtures, binder: sand ratio was kept constant as $1: 2.75$ by weight. Mixtures containing CEM I and SRPC were prepared with a w/b ratio of 0.485 . Mixtures containing scoriabased blended cements were prepared by changing the $\mathrm{w} / \mathrm{b}$ ratio in order to obtain a flow within \pm 5 of that of the CEM I mortar. For acid attack tests, a set of three cubes from each mixture was cast for each of acid solution and curing age. For sulfate attack test, prismatic mortar bars and cubes were cast from each mixture in accordance with ASTM C1012 (2004).

\subsection{Concrete Mixes}

Seven concrete mixes were prepared using a grading of aggregate mixtures kept constant for all concretes. Aggregates used in the study were crushed dolomite with river bed natural sand added. Both aggregates were obtained from 
Table 2 Chemical, physical and mechanical properties of plain and blended cements.

\begin{tabular}{|c|c|c|c|c|c|c|c|c|}
\hline $\begin{array}{c}\text { Chemical } \\
\text { composition } \\
(\%) \\
\end{array}$ & C1/CEMI & $\mathrm{C} 2 / 10 \%$ & $\mathrm{C} 3 / 15 \%$ & $\mathrm{C} 4 / 20 \%$ & $\mathrm{C} 5 / 25 \%$ & C6/30 \% & $\mathrm{C} 7 / 35 \%$ & C8/SRPC \\
\hline \multicolumn{9}{|c|}{ Chemical properties of plain and blended cements } \\
\hline $\mathrm{SiO}_{2}$ & 20.69 & 21.59 & 22.35 & 23.25 & 24.00 & 24.33 & 24.61 & 20.72 \\
\hline $\mathrm{Al}_{2} \mathrm{O}_{3}$ & 5.09 & 5.20 & 5.68 & 5.73 & 6.55 & 6.80 & 7.39 & 4.33 \\
\hline $\mathrm{Fe}_{2} \mathrm{O}_{3}$ & 4.23 & 4.75 & 4.79 & 5.15 & 5.43 & 5.47 & 6.31 & 5.79 \\
\hline $\mathrm{CaO}$ & 60.62 & 58.21 & 55.18 & 53.05 & 50.30 & 48.00 & 44.84 & 61.69 \\
\hline $\mathrm{MgO}$ & 2.46 & 2.66 & 3.23 & 3.39 & 3.87 & 4.11 & 4.63 & 1.21 \\
\hline $\mathrm{SO}_{3}$ & 2.26 & 2.31 & 2.20 & 2.20 & 2.30 & 2.26 & 2.55 & 2.13 \\
\hline $\begin{array}{l}\text { Loss on } \\
\text { ignition }\end{array}$ & 1.41 & 1.40 & 1.43 & 1.37 & 1.47 & 1.48 & 1.60 & 2.90 \\
\hline $\mathrm{Na}_{2} \mathrm{O}$ & 0.60 & 0.71 & 0.83 & 0.94 & 1.07 & 1.16 & 1.31 & 0.21 \\
\hline $\mathrm{K}_{2} \mathrm{O}$ & 0.35 & 0.39 & 0.43 & 0.46 & 0.50 & 0.53 & 0.57 & 0.19 \\
\hline $\mathrm{Cl}^{-}$ & 0.023 & 0.021 & 0.022 & 0.019 & 0.018 & 0.019 & 0.019 & 0.022 \\
\hline $\begin{array}{l}\text { Insoluble } \\
\text { residue }\end{array}$ & 1.03 & 1.58 & 2.09 & 2.51 & 3.48 & 4.08 & 5.33 & 0.36 \\
\hline \multicolumn{9}{|c|}{ Main compounds of clinker used in cement specimens (Based on Bogue composition) } \\
\hline $\mathrm{C} 3 \mathrm{~S}$ & 53.36 & 50.55 & 47.74 & 44.94 & 42.13 & 39.32 & 36.51 & 50.16 \\
\hline $\mathrm{C} 2 \mathrm{~S}$ & 17.76 & 16.82 & 15.89 & 14.95 & 14.02 & 13.08 & 12.15 & 21.58 \\
\hline $\mathrm{C} 3 \mathrm{~A}$ & 5.78 & 5.47 & 5.17 & 4.86 & 4.56 & 4.26 & 3.95 & 1.69 \\
\hline C4AF & 11.53 & 10.93 & 10.32 & 9.71 & 9.11 & 8.50 & 7.89 & 17.60 \\
\hline $\mathrm{C} 3 \mathrm{~S} / \mathrm{C} 2 \mathrm{~S}$ & 3.0 & 3.0 & 3.0 & 3.0 & 3.0 & 3.0 & 3.0 & 2.32 \\
\hline \multicolumn{9}{|c|}{ Physical properties of plain and blended cements } \\
\hline $\begin{array}{l}\text { Specific } \\
\text { gravity }\end{array}$ & 3.13 & 3.09 & 3.05 & 3.02 & 2.99 & 2.98 & 2.96 & \\
\hline $\begin{array}{l}\text { Initial } \\
\text { setting } \\
(\min )\end{array}$ & 151 & 153 & 153 & 153 & 152 & 153 & 158 & \\
\hline $\begin{array}{c}\text { Final setting } \\
(\min )\end{array}$ & 178 & 179 & 180 & 180 & 179 & 181 & 188 & \\
\hline $\begin{array}{c}\text { Water } \\
\text { demand }(\%)\end{array}$ & 25.1 & 25.2 & 25.2 & 25.4 & 25.4 & 25.4 & 25.5 & \\
\hline $\begin{array}{c}\text { Soundness } \\
(\mathrm{mm})\end{array}$ & 0.6 & 0.7 & 0.8 & 0.8 & 0.9 & 1.1 & 0.9 & \\
\hline $\begin{array}{c}\text { Residue on } \\
45 \mu \mathrm{m} \text { sieve } \\
(\%)\end{array}$ & 13.6 & 14.3 & 14.8 & 15.2 & 16.1 & 17.0 & 17.9 & \\
\hline $\begin{array}{c}\text { Residue on } \\
90 \mu \mathrm{m} \text { sieve } \\
(\%)\end{array}$ & 6.4 & 6.2 & 6.4 & 6.5 & 6.7 & 6.9 & 6.8 & \\
\hline \multicolumn{9}{|c|}{ Mechanical properties of plain and blended cement mortars } \\
\hline $\begin{array}{c}\text { Strength of } \\
\text { mortars at } \\
28 \text { days } \\
\text { curing } \\
(\mathrm{MPa})\end{array}$ & 45.6 & 44.2 & 42.3 & 40.6 & 37.1 & 33.7 & 30.6 & \\
\hline
\end{tabular}




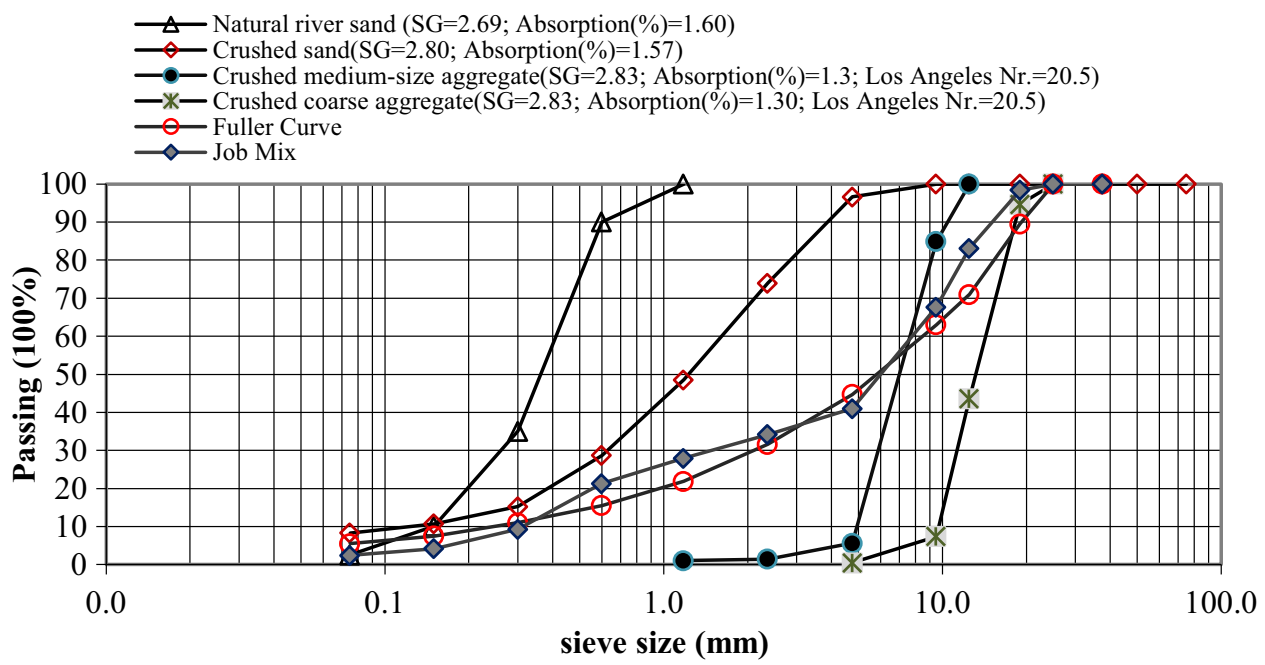

Fig. 3 Grading curves of aggregates used in the concrete mixes with some physical properties.

local sources. Chemical composition and grading with some physical properties of the aggregates are illustrated in Table 1 and Fig. 3, respectively. Their quantities in $1 \mathrm{~m}^{3}$ concrete mix based on the oven-dry condition are as follows: $565.5 \mathrm{~kg}$ of coarse aggregate, $565.5 \mathrm{~kg}$ of medium-size aggregate, $447.5 \mathrm{~kg}$ of coarse sand and $286.5 \mathrm{~kg}$ of natural sand. All concrete mixes were designed to have a waterbinder ratio of 0.6 and a slump of $150 \pm 20 \mathrm{~mm}$. This $\mathrm{w} / \mathrm{b}$ ratio was kept constant in order to directly observe the effects of adding scoria as cement partial replacement on properties of concrete.

Six concrete cubes $(150 \mathrm{~mm})$ were cast for each of binders and curing ages for the determination of compressive strength. Three plain concrete cylinders $(100 \mathrm{~mm} \times$ $200 \mathrm{~mm}$ ) for each of binder type and curing age were cast, for evaluating the chloride penetrability. The RC specimen for the accelerated corrosion tests was $100 \mathrm{~mm} \times 200 \mathrm{~mm}$ concrete cylinder in which $12 \mathrm{~mm}$ diameter steel bar was centrally embedded. The steel bar was embedded into the concrete cylinder such that its end was at least $45 \mathrm{~mm}$ from the bottom of the cylinder, and it was coated with epoxy at the exit from the concrete cylinder in order to eliminate crevice corrosion. Three specimens for each binder type and curing age were cast.

\subsection{Compressive Strength Test of Concrete}

The compressive strength development was determined on $150 \mathrm{~mm}$ cubic concrete specimens, in accordance with ISO 4012 (1978), after 2, 7, 28, 56 and 90 days curing.

\subsection{Rapid Chloride Penetrability Test}

The test was conducted in accordance with ASTM C 1202 (2001). Three slices of $100 \mathrm{~mm}$ in diameter and $50 \mathrm{~mm}$ in thickness were cut from the middle portion of each concrete cylinder specimens $(100 \mathrm{~mm} \times 200 \mathrm{~mm})$. The set-up of RCPT is illustrated in Fig. 4. The total charge passed through the sample, in coulombs, is determined by calculating the area under the current-time plot during the 6-h test period. It is generally agreed that for low-permeability concretes, the value of the charge, in coulombs, passed through the specimens should not exceed 2000. Three cylinder specimens of each concrete mix were tested after 28 and 90 days curing.

\subsection{Accelerated Corrosion Test}

A rapid corrosion test was used to compare the corrosion performance of concretes containing binders produced. Similar techniques with little differences were reported by other researchers (Horsakulthai et al. 2011; Parande et al. 2008; Ha et al. 2007; Saraswathy and Song 2007; Guneyisi et al. 2005; Rossignolo and Agesini 2004; Shaker et al. 1997; Khedr and Idriss 1995; Al-Tayyib and Al-Zahrani 1990). In the study, RC specimens were immersed in a $15 \%$ $\mathrm{NaCl}$ solution leveling the half of the concrete cylinder and the steel bar (working electrode) was connected to the positive terminal of a DC power source while the negative terminal was connected to a steel plate (counter electrode) placed near the concrete specimen in the solution. The corrosion process was initiated by impressing a relatively high anodic potential of $12 \mathrm{~V}$ to accelerate the corrosion process.

Figure 5 shows a schematic representation of the experimental setup for the accelerated corrosion test. The specimens were monitored periodically to see how long it takes for corrosion cracks to appear on the specimen surface. The current readings with time were recorded at $4 \mathrm{~h}$-intervals. Three specimens from each concrete mix were tested after 28 and 90 days curing.

\subsection{Acid Attack Test}

The relative acid resistance was determined in accordance with ASTM C267 (2001). The aggressive acid environmental conditions were simulated using the following acids: $5 \%$ sulfuric acid $\left(\mathrm{H}_{2} \mathrm{SO}_{4}\right), 10 \%$ hydrochloric acid $(\mathrm{HCl})$, $5 \%$ nitric acid $\left(\mathrm{HNO}_{3}\right)$ and $10 \%$ acetic acid $\left(\mathrm{CH}_{3} \mathrm{COOH}\right)$ of $\mathrm{pH}$ equal to $0.5,0.25,0.45$ and 2.2 , respectively. The 28 and 90 days cured mortar cubes were immersed in these 


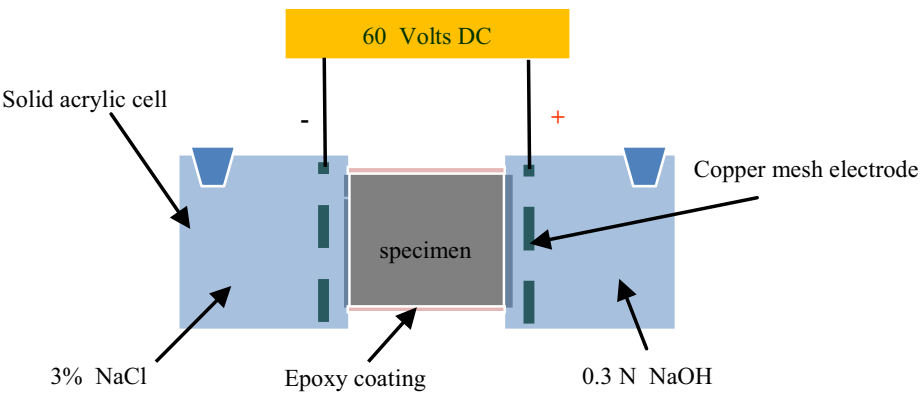

(a)

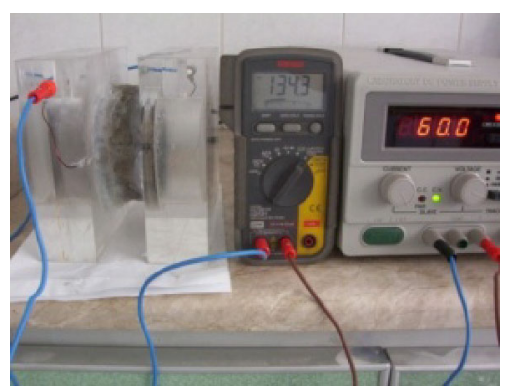

(b)

Fig. 4 Experimental setup of rapid chloride penetration test. a Schematic representation of experimental setup of rapid chloride penetration test. b View of experimental setup (one of current readings for $\mathrm{C} 2 / 10 \%$ specimen).

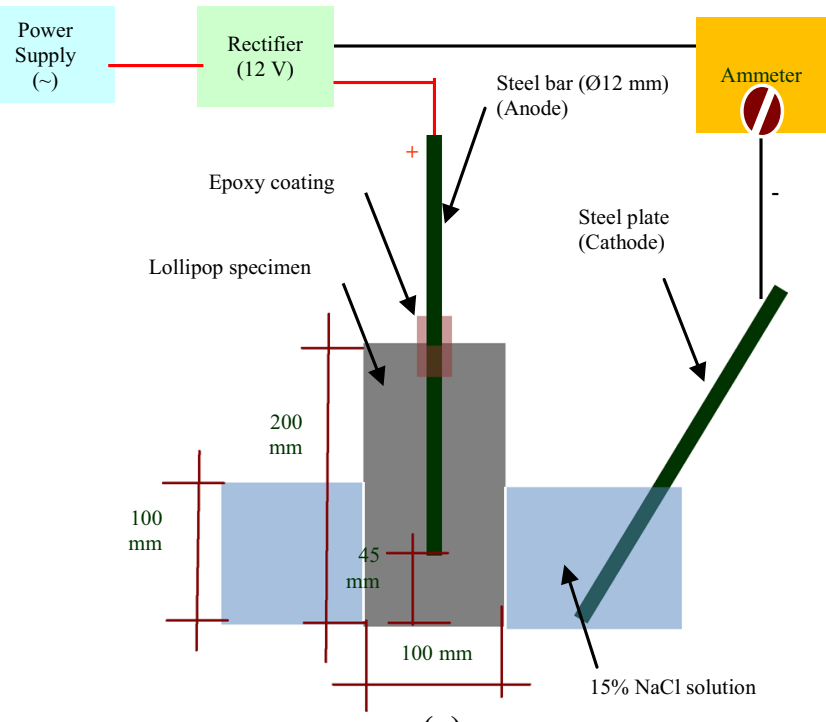

(a)

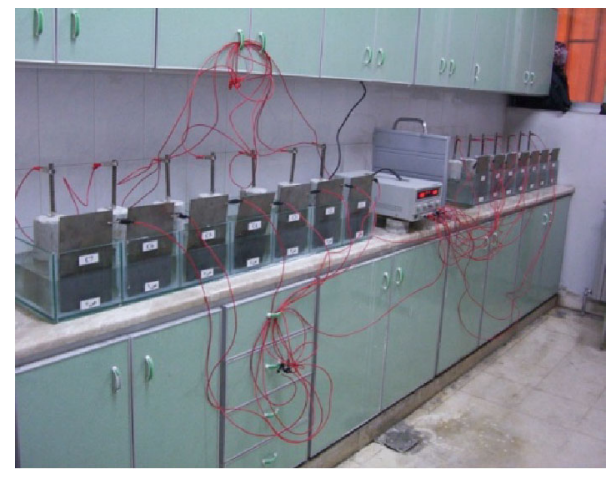

(b)

Fig. 5 Schematic representation and view of experimental setup for the accelerated corrosion test. a Setup for the accelerated corrosion test. b. View of the experimental setup.

aggressive acid environments for 100 days. The Plexiglas containers with immersed mortar specimens were kept covered throughout the testing period to minimize the evaporation. At 2, 7, 14, 28, 56, 84 and 100 days of exposure, the mortar specimens were cleaned with distilled water, then the acid resistance was evaluated through measurement of the weight loss of the specimens determined as follows: Weight loss $(\%)=\left[\left(W_{1}-W_{t}\right) / W_{1}\right] \times 100$, where $W_{1}$ is the weight (grams) of the specimens before immersion and $W_{t}$ is the weight (grams) of cleaned specimens after $t$ day immersion. The average weight losses for each mortar cubes have been reported.

\subsection{Sulfate Attack Test}

The evaluation of sulfate attack resistance of mortars was performed in accordance with ASTM C1012 (2004). Length measurements of the prepared prismatic specimens were performed at 1, 2, 3, 4, 8, 13, 15, 17, 26, 38, 52 weeks after immersing the specimens into the sulfate $\left(5 \% \mathrm{Na}_{2} \mathrm{SO}_{4}\right)$ solution. The solution was renewed four times throughout the test; at $8,17,26$ and 38 weeks.

\section{Discussion of Results}

\subsection{Properties of Scoria and Blended Cements}

As seen from Table 1, scoria is considered as suitable material for use as pozzolan. It satisfied the standards requirements for such a material by having a combined $\mathrm{SiO}_{2}$, $\mathrm{Al}_{2} \mathrm{O}_{3}$ and $\mathrm{Fe}_{2} \mathrm{O}_{3}$ of more than $70 \%$, a $\mathrm{SO}_{3}$ content of less than $4 \%$ and a loss on ignition of less than $10 \%$ (ASTM 2001). $\mathrm{SiO}_{2 \text { reactive }}$ content is more than $25 \%$, as well (EN 2004). In addition, it has a strength activity index with PC higher than the values specified in ASTM C618 (2001). The chemical and physical properties of scoria-based blended cements are also in conformity with the standards requirements (ASTM 2001). Their contents of $\mathrm{MgO}$ and $\mathrm{SO}_{3}$ are less than 6 and $4 \%$, respectively. The loss on ignition is also less than $5 \%$ as specified in ASTM C595 (2001). Setting time and soundness values meet the limits specified in ASTM C595 (2001), for all binder types. The compressive strengths of blended cement mortars are lower than that of the plain PC at 28 days curing. This reduction is mainly due to the slowness of pozzolanic reaction between pozzolan and 
Table 3 Compressive strength of concrete cubes.

\begin{tabular}{c|c|c|c|c|c}
\hline \multirow{2}{*}{ Sample } & \multicolumn{5}{|c}{ Compressive strength (MPa)-normalized } \\
\cline { 2 - 6 } & 2 days (\%) & 7 days (\%) & 28 days (\%) & 56 days (\%) & 90 days (\%) \\
\hline \hline C1/CEM I (control) & $13.6-100$ & $24.9-100$ & $35.0-100$ & $40.6-100$ & $42.3-100$ \\
\hline C2/10 \% & $12.8-94$ & $24.4-98$ & $33.6-96$ & $39.8-98$ & $41.6-98$ \\
\hline C3/15\% & $11.8-87$ & $21.0-84$ & $30.1-86$ & $37.0-91$ & $39.3-93$ \\
\hline C4/20\% & $11.0-81$ & $20.1-81$ & $29.5-84$ & $35.1-86$ & $38.3-91$ \\
\hline C5/25\% & $9.9-73$ & $17.6-71$ & $26.5-76$ & $31.8-78$ & $36.5-86$ \\
\hline C6/30\% & $8.9-65$ & $16.5-66$ & $24.6-70$ & $29.6-73$ & $33.1-78$ \\
\hline C7/35\% & $8.5-63$ & $16.0-64$ & $23.4-67$ & $28.0-69$ & $30.9-73$ \\
\hline
\end{tabular}

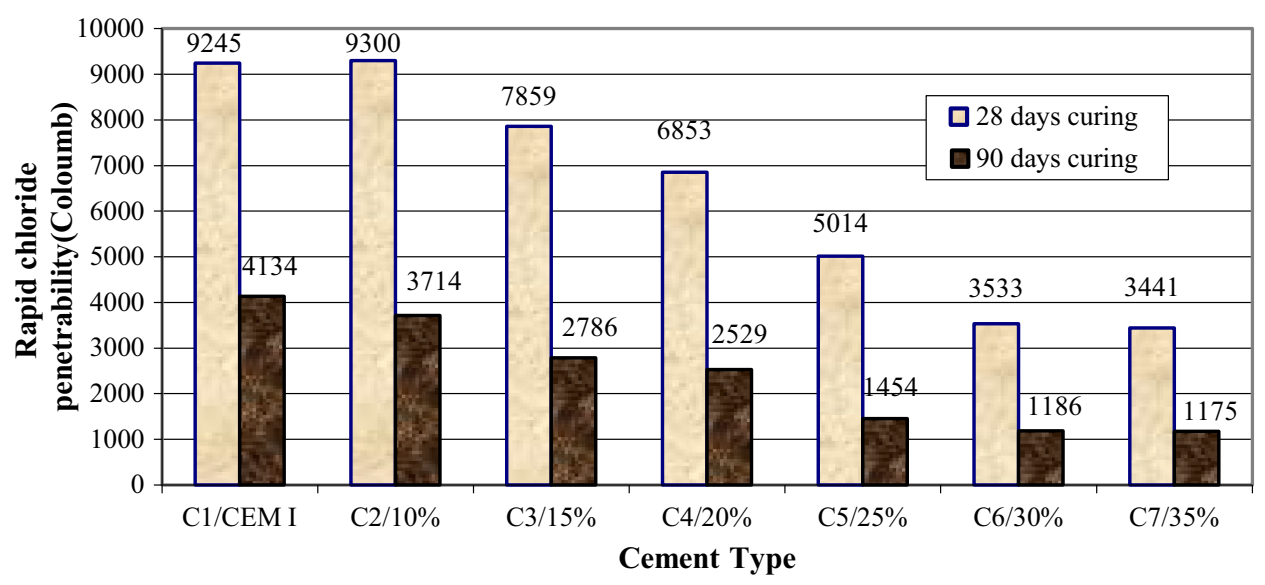

Fig. 6 Influence of scoria content on chloride penetrability of concrete.

$\mathrm{CH}$ released during cement hydration (Mindess et al. 2003), and could be due the coarser blended cement particles, as shown in Table 2.

\subsection{Compressive Strength of Concretes}

Results of compressive strength test are summarized in Table 3. As expected, the compressive strength of the concrete increases with curing time with a high rate of strength gains at early ages which gradually decrease at longer ages. Plain cement concrete specimens have higher compressive strengths at any age when compared with blended cement concretes. The compressive strength at 7 days decreases from 24.9 to $16.0 \mathrm{MPa}$ when CEM I and CEM II/B-P with $35 \%$ of scoria were used, respectively. The relative compressive strength after 2 days curing with $35 \%$ of scoria is only $63 \%$ of that of CEM I specimens. This could be explained by the slowness of the pozzolanic reaction between the glassy phase in scoria and the $\mathrm{CH}$ released during cement hydration. However, due to the continuation of this reaction and the formation of a secondary $\mathrm{C}-\mathrm{S}-\mathrm{H}$, a greater degree of hydration is achieved resulting in strengths after 90 days curing which are comparable to those of CEM I specimens.

\subsection{Rapid Chloride Penetrability}

Results of rapid chloride penetrability test are shown in Fig. 6. The resistance to chloride penetration was greatly increased with the use of scoria-based blended cement concretes. The total charge passed is substantially reduced with increase in scoria content and curing time. The total charge passed through concrete mix containing C5/25\% binder type after 28 days curing was about half of the control mix, and decreased to about one third after 90 days curing. None of concretes has a total charge passed less than 2000 coulombs after 28 days curing. This expected result may be due to the high $\mathrm{w} / \mathrm{b}$ ratio. However, the concretes containing CEM II/B-P with scoria contents of 25,30 and $35 \%$, showed the best performance among all the specimens. According to ASTM C1202 (2001), these concretes can be considered as low chloride permeable after 90 days curing. The improvement in resistance to chloride penetration may be related to the refined pore structure of these concretes and their reduced electrical conductivity (Talbot et al. 1995). This which was confirmed by many researchers (Ghrici et al. 2006; Rukzon and Chindaprasirt 2009; Chindaprasirt et al. 2007; Gastaldini et al. 2007; Pourkhorshidi et al. 2010; Ramezanianpour et al. 2010; Hossain et al. 2008; Rukzon and Chindaprasirt 2009; Chindaprasirt et al. 2007; Gastaldini et al. 2007), is due to the secondary pozzolanic reaction which contributes to make the microstructure of concrete denser. If a higher volume of scoria is added, much lower penetrability can be achieved. 


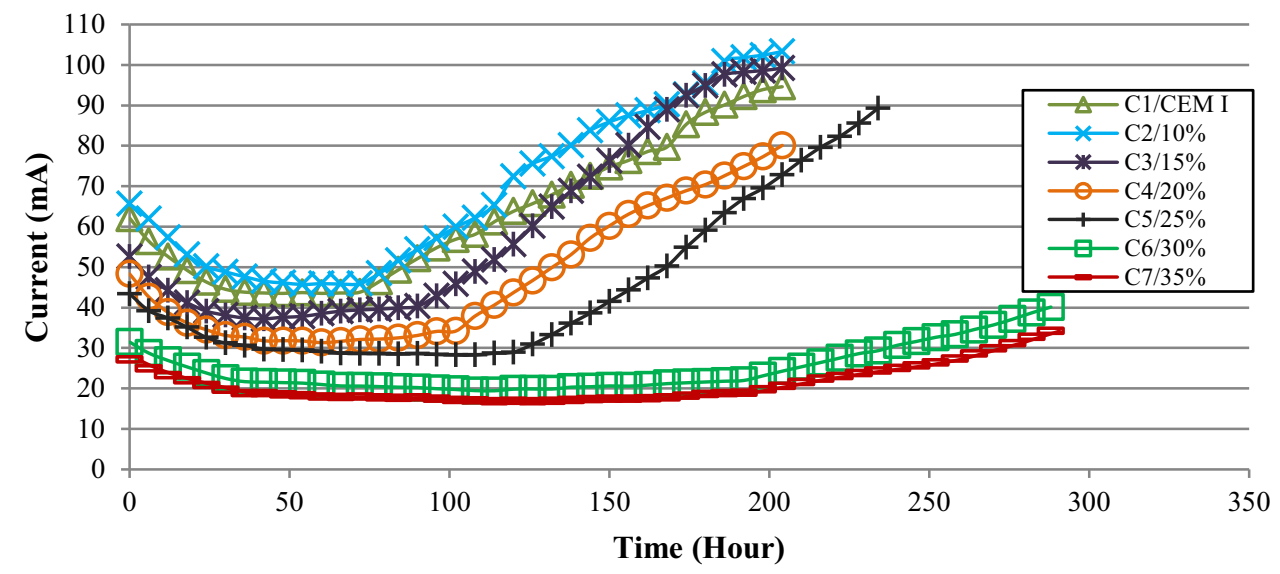

Fig. 7 Typical curve of corrosion current versus time of concrete specimens tested after 28 days curing.

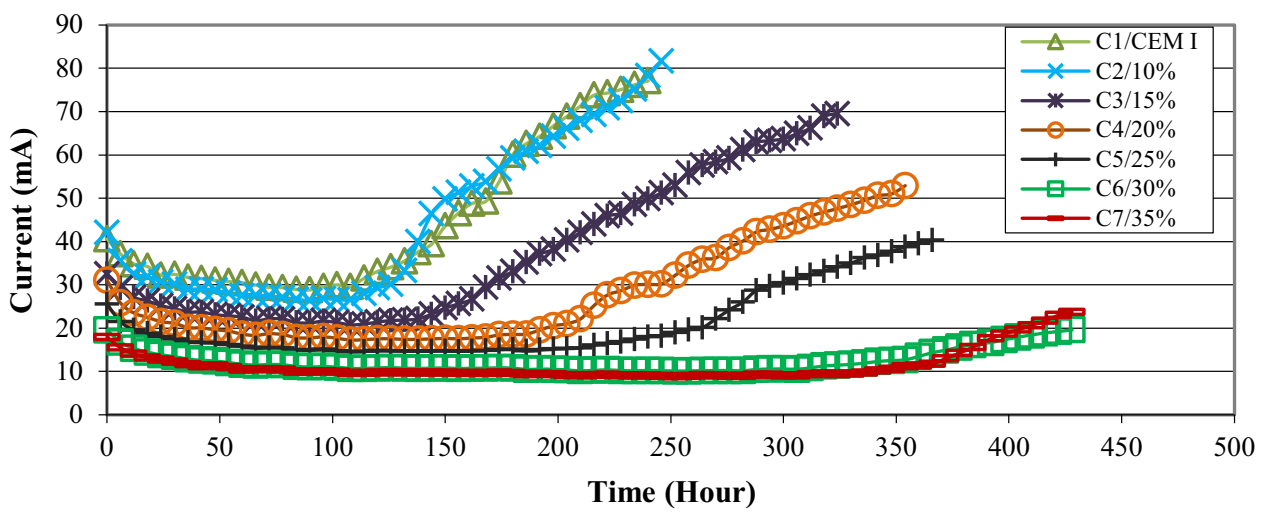

Fig. 8 Typical curve of corrosion current versus time of concrete specimens tested after 90 days curing.

\subsection{Corrosion Resistance}

Typical curves of corrosion current versus time for the concrete specimens made with CEM I, CEM II/A-P and CEM II/B-P binder types are illustrated in Figs. 7 and 8, respectively. As seen from Figs. 7 and 8, current-time curve initially descended till a time value after which a steady low rate of increase in current was observed, and after a specific time period a rapid increase in current was detected until failure. The decreasing tendency of current at the very early time could be explained by the filling of the pores with salt and other deposits in the salt water (Reddy et al. 2011). Almost a similar variation of the corrosion current with time has also been observed by other researchers (Horsakulthai et al. 2011; Guneyisi et al. 2005). The first visual evidence of corrosion was the appearance of brown stains on the surface of the specimens. Cracking was observed shortly thereafter, and it was associated with a sudden rise in the current. Figure 9 presents the average corrosion times required to crack the specimens made with CEM I, CEM II/A-P and CEM II/B-P. Time to cracking in CEM I concrete specimens was in the range of 70-106 h (3-5 days), whereas that in CEM II/B-P was in the range of 120-370 h (5-16 days), depending on the replacement level and age at testing. The best corrosion resistance was obtained from blended cements with $35 \%$ additive ratio. The test lasted for 194 and $370 \mathrm{~h}$ in this specimen after 28 and 90 days curing times,

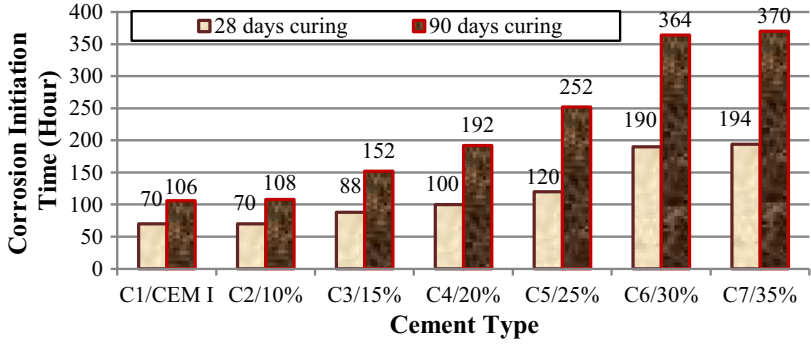

Fig. 9 Average corrosion times of specimens at 28 and 90 days curing.

respectively. Results also demonstrated that the increase in time to cracking with test age (from 28 to 90 days) was greater in almost all of the cases for the scoria-based cement concrete specimens when compared with the plain concrete specimens. This delay in corrosion time when using blended cements may be related to the pozzolanic reaction of scoria which contributes to fill the voids and pores in concrete with an additional $\mathrm{C}-\mathrm{S}-\mathrm{H}$ gel. This leads to decrease of pore size and to a smaller effective diffusivity for chloride (Guneyisi et al. 2005; Hossain 2003). This can improve the long-term corrosion resistance of RC structures, and make concrete denser and less permeable (Guneyisi et al. 2005; Hossain 2003). Also, It was noted from Figs. 7 and 8 the corrosion resistance of most of blended cement concrete specimens 


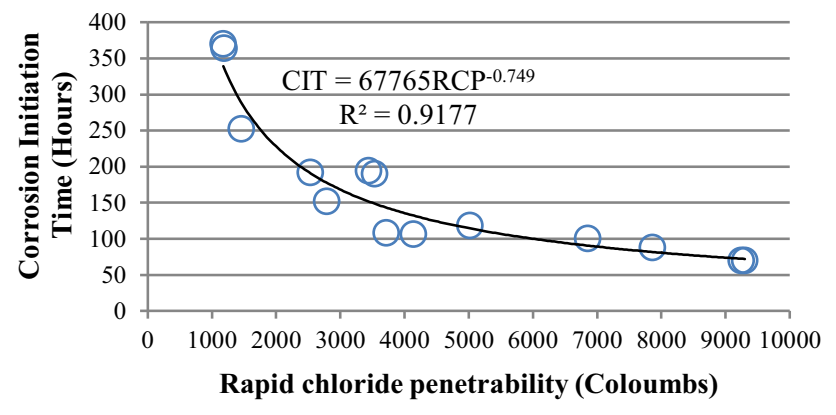

Fig. 10 Variation of corrosion initiation time with rapid chloride penetrability.

increased significantly with age while that of the plain cement concrete had a slightly increase which has also been indicated by other researchers (Guneyisi et al. 2005).

\subsection{Corrosion Initiation Time Versus Chloride Penetrability of Concrete}

It was observed from Fig. 10 that the corrosion initiation time and chloride penetrability of concrete are closely related to each other. The analysis results showed that there is a good correlation between corrosion initiation time and total charge passed through concrete specimens, with a regression coefficient $\left(\mathrm{R}^{2} \approx 0.92\right)$. According to Montgomery and Peck (1982) a regression coefficient, $\mathrm{R}^{2}$, of more than 0.85 indicates an excellent correlation between the fitted parameters. Increasing the total charge passed through concrete specimens reduces the time to initiate corrosion.

\subsection{Acid Attack}

The resistance to acid solutions was measured by means of the weight loss of the mortar cubes. Figures 11, 12, 13 and

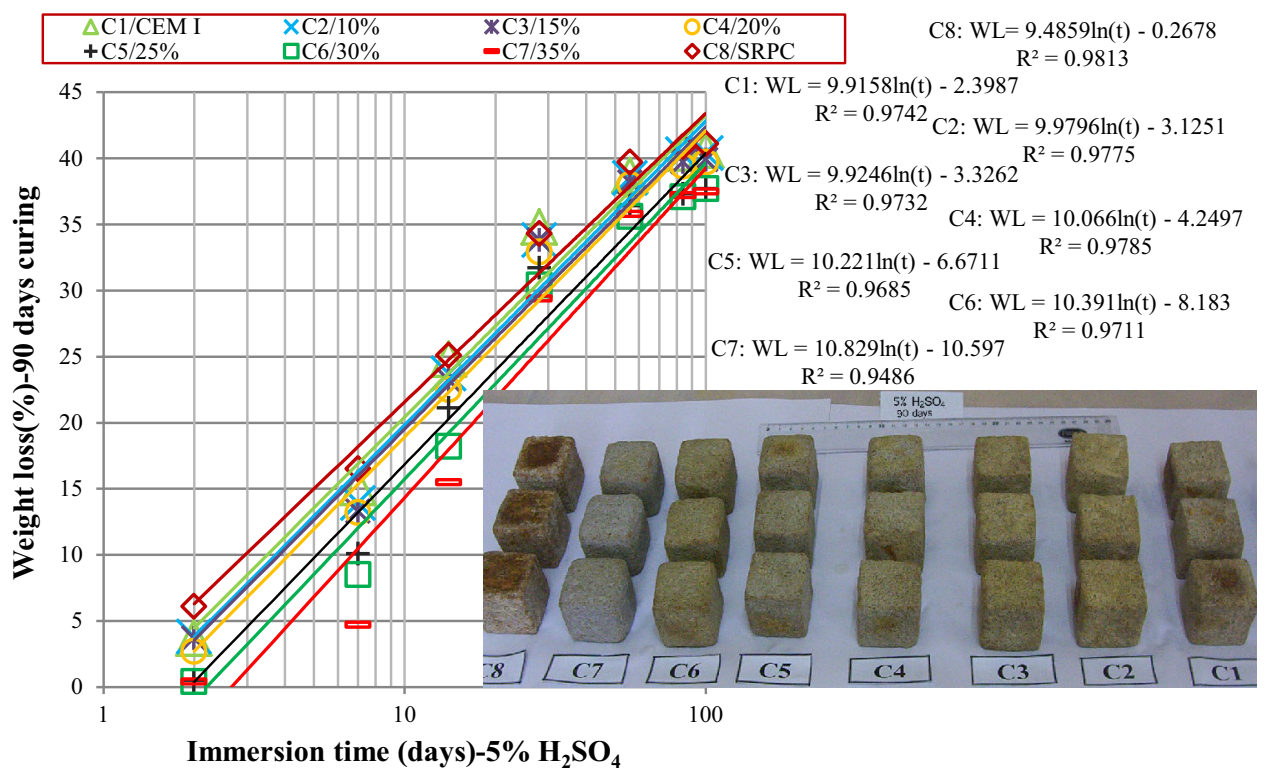

Fig. 11 Weight losses over time of 90 days cured mortars immersed in $5 \% \mathrm{H}_{2} \mathrm{SO}_{4}$ solution.

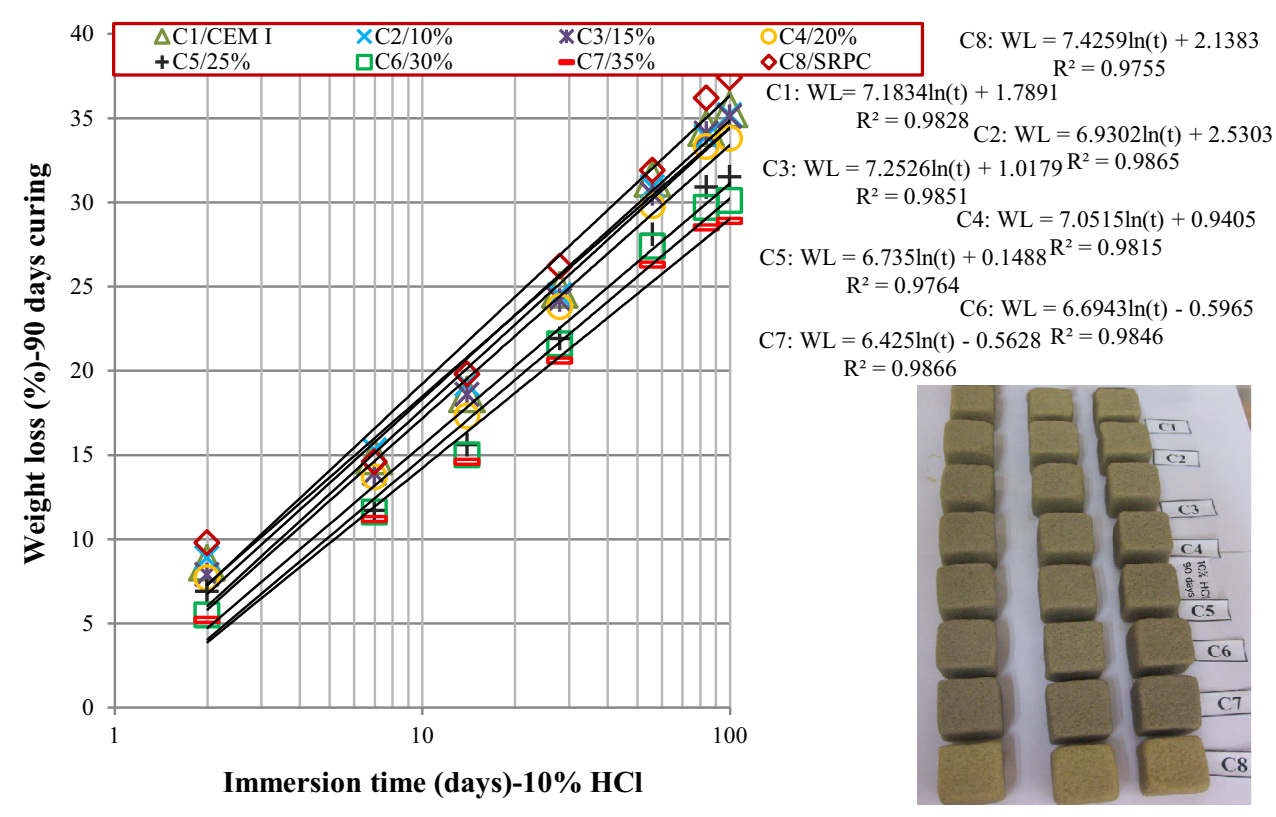

Fig. 12 Weight losses over time of 90 days cured mortars immersed in $10 \% \mathrm{HCl}$ solution. 


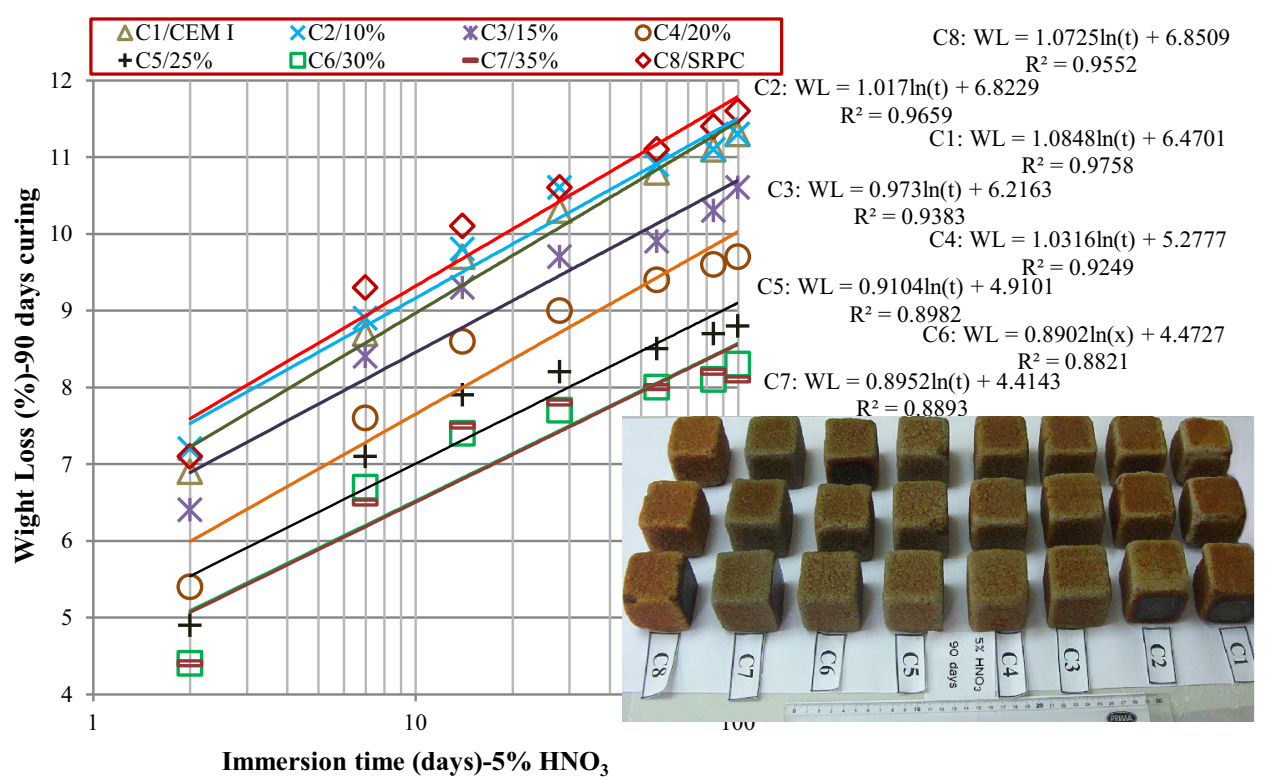

Fig. 13 Weight losses over time of 90 days cured mortars immersed in $5 \% \mathrm{HNO}_{3}$ solution.

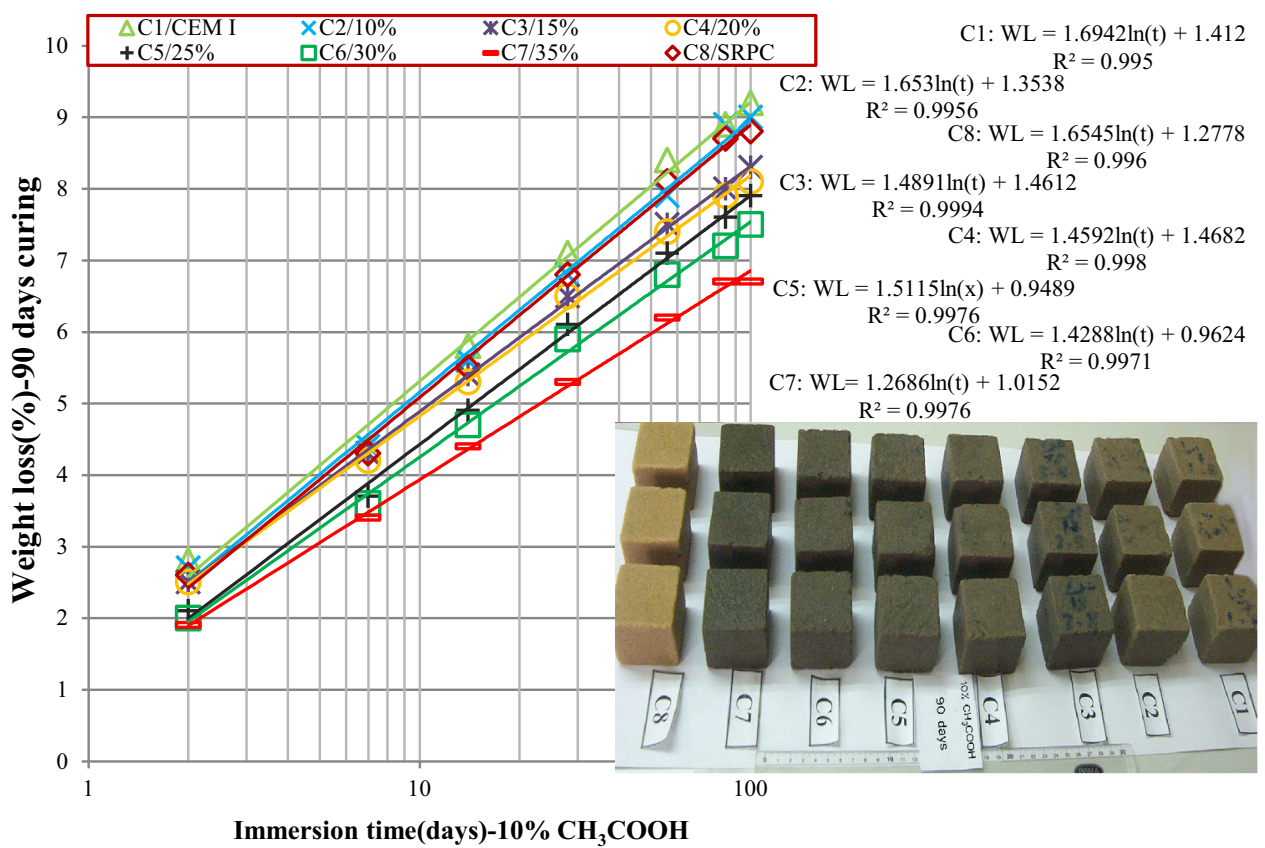

Fig. 14 Weight losses over time of 90 days cured mortars immersed in $10 \% \mathrm{CH}_{3} \mathrm{COOH}$ solution.

14 show the weight loss of 90 days cured mortar cubes immersed in $5 \% \mathrm{H}_{2} \mathrm{SO}_{4}, 10 \% \mathrm{HCl}, 5 \% \mathrm{HNO}_{3}$ and $10 \%$ $\mathrm{CH}_{3} \mathrm{COOH}$ solutions, respectively.

The weight loss is considered as a function of time. As expected, the acid resistance of the mortars improves with increasing the replacement level of scoria. This improvement of acid resistance is higher at early ages and decreases with increasing the immersion time. Beyond 28 days of exposure, slight improvements in acid resistance have been found. For instance, weight loss in 90 days cured mortars dropped from $34.8 \%$ (CEM I) to $29.4 \%(\mathrm{C} 7 / 35 \%)$ after 28 days of exposure to $5 \% \mathrm{H}_{2} \mathrm{SO}_{4}$. From Figs. 11, 12, 13 and 14, SRPC and CEM I suffered the most deterioration in terms of weight loss at earlier ages of exposure to all acid solutions. The weight loss of the CEM II/B was between half and threequarters of the weight loss of the CEM I mixture at the first seven days of exposure. The number of days needed to register a $10 \%$ loss in weight is considered in the evaluation. As seen from Table 4, the $10 \%$ weight loss was obtained with the $\mathrm{C} 7 / 35 \%$ mix at up to 6.2 and 6.70 days of exposure to sulfuric acid; 4.6 and 5.2 days of exposure to hydrochloric acid at 28 and 90 days curing, respectively. The SRPC and CEM I mixtures, however, reached the same weight loss at only 3.0 and 3.5 days when exposed to sulfuric acid; at $3.2 \& 2.9$ days and $3.7 \& 3.2$ days when exposed to hydrochloric acid at 28 and 90 days curing, respectively. None of CEM II/B mixtures lost $10 \%$ weight even after 100 days of exposure to nitric and acetic acids. 
Table 4 Number of days needed to register a $10 \%$ weight loss of mortar cubes.

\begin{tabular}{c|c|c|c|c|c|c|c|c}
\hline \multirow{2}{*}{ Cement type } & \multicolumn{7}{|c}{ Number of days to register $10 \%$ weight loss } \\
\cline { 2 - 10 } & \multicolumn{2}{|c|}{$5 \% \mathrm{H}_{2} \mathrm{SO}_{4}$} & \multicolumn{2}{c}{$10 \% \mathrm{HCl}$} & \multicolumn{2}{c}{$5 \% \mathrm{HNO}_{3}$} & \multicolumn{2}{c}{$10 \% \mathrm{CH}_{3} \mathrm{COOH}$} \\
\cline { 2 - 10 } & 28 days curing & 90 days curing & 28 days curing & 90 days curing & 28 days curing & 90 days curing & 28 days curing & 90 days curing \\
\hline \hline $\mathrm{C} 1 / \mathrm{CEMI}$ & 3.5 & 3.5 & 3.7 & 3.2 & 22.5 & 25.9 & $\mathrm{NR}$ & $\mathrm{NR}$ \\
\hline $\mathrm{C} 2 / 10 \%$ & 3.7 & 3.7 & 3.7 & 3.1 & 25.4 & 22.8 & $\mathrm{NR}$ & $\mathrm{NR}$ \\
\hline $\mathrm{C} 3 / 15 \%$ & 3.8 & 3.8 & 3.8 & 3.6 & 55.5 & 48.9 & $\mathrm{NR}$ & $\mathrm{NR}$ \\
\hline $\mathrm{C} 4 / 20 \%$ & 4.0 & 4.1 & 3.9 & 3.7 & 79.1 & 97.3 & $\mathrm{NR}$ & $\mathrm{NR}$ \\
\hline $\mathrm{C} 5 / 25 \%$ & 4.7 & 5.1 & 4.1 & 4.3 & $\mathrm{NR}$ & $\mathrm{NR}$ & $\mathrm{NR}$ & $\mathrm{NR}$ \\
\hline $\mathrm{C} 6 / 30 \%$ & 5.2 & 5.8 & 4.4 & 4.9 & $\mathrm{NR}$ & $\mathrm{NR}$ & $\mathrm{NR}$ & $\mathrm{NR}$ \\
\hline $\mathrm{C} 7 / 35 \%$ & 6.2 & 6.7 & 4.6 & 5.2 & $\mathrm{NR}$ & $\mathrm{NR}$ & $\mathrm{NR}$ & $\mathrm{NR}$ \\
\hline $\mathrm{C} 8 / \mathrm{SRPC}$ & 3.0 & 3.0 & 3.2 & 2.9 & 20.1 & 18.8 & $\mathrm{NR}$ & $\mathrm{NR}$ \\
\hline
\end{tabular}

NR $10 \%$ weight loss was not reached.

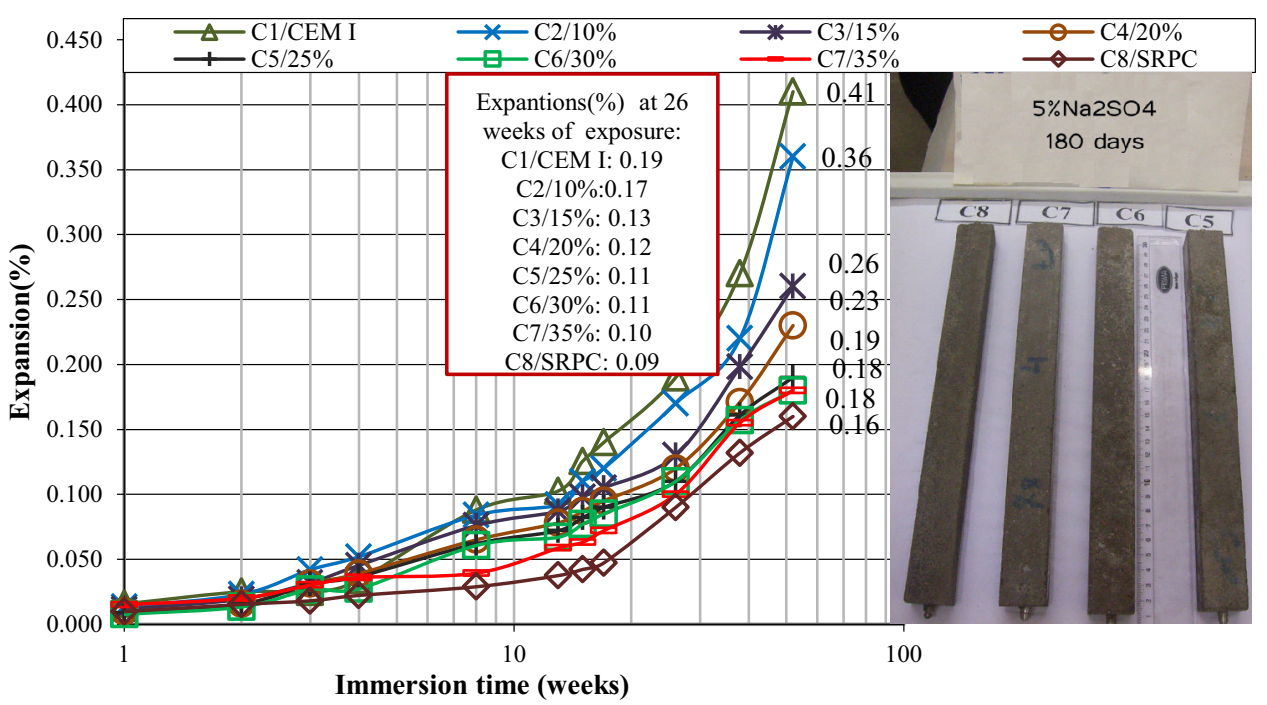

Fig. 15 Length changes over time of prismatic mortars immersed in $5 \% \mathrm{Na}_{2} \mathrm{SO}_{4}$.

The overall degree of attack tended to be more severe in sulfate and hydrochloric solutions compared with nitric and acetic acids.

The better performance of scoria-based cements can be due to the pozzolanic reaction (Cao et al. 1997; Aydın et al. 2007). This reaction between scoria and calcium hydroxide liberated during the hydration of cement (Aydın et al. 2007), led to a refinement of the pore structure resulting in a highly impermeable matrix (Cao et al. 1997). The pozzolanic reaction also fixes $\mathrm{Ca}(\mathrm{OH})_{2}$, which is usually the most vulnerable product of hydration of cement in so far as acid attack is concerned (Neville 2011). Contrary to expectation, the weight loss of SRPC mortars was very similar to that of CEM I mortars under similar conditions. This is possibly because SRPC and CEM I mortars both contain lime and calcium silicates in large proportions. This was in agreement with results of Fattuhi and Hughes (1988). It should be also noted that after 100 days of exposure to acid solutions, especially sulfuric and nitric acids, SRPC and, to a smaller degree, CEM I mortar cubes showed a surface layer of brown color. This brown-colored layer, which is probably composed of ferric oxides (Pavlik 1994), can be attributed to the higher content of $\mathrm{C}_{4} \mathrm{AF}$ in both cements. Generally, all acid attacks on mortars are associated with erosion and softening due to leaching of $\mathrm{Ca}$ and decalcification of $\mathrm{C}-\mathrm{S}-$ $\mathrm{H}$ (Cao et al. 1997). Hence, expansion might be expected to be less with the reduced $\mathrm{pH}$ values (Cao et al. 1997). As generally expected, none of all binders used can provide a long-term resistance when exposed to strong acids.

\subsection{Sulfate Attack}

The results of the expansion test of bars immersed in $5 \%$ $\mathrm{Na}_{2} \mathrm{SO}_{4}$ solution for up to 52 weeks are shown in Fig. 15. It was clearly seen form Fig. 15, the use of scoria reduced expansion of the mortar bars. This reduction in expansion increased with increase in the scoria replacement level. These results were similar to those of other studies in which pozzolanic materials were used as cement replacements to 
improve sulfate resistance (Tangchirapat et al. 2009; Irassar et al. 2000). It should be also noted that the amount of expansion for SRPC mortar bars was very similar to that of CEM II/B mortar bars. At 26 and 52 weeks, the amount of expansion of the CEM II/B mortar bars ranged from $0.10 \%$ to $0.11 \%$ and from $0.18 \%$ to $0.19 \%$, respectively, whereas the expansion of SRPC was 0.09 and $0.16 \%$, respectively. This was despite the lack of $\mathrm{C}_{3} \mathrm{~A}$ in SRPC. The slightly elevated expansion noted in SRPC used in the study, which made it unsuitable for severe exposure, is possibly because the SRPC mortar contains lime and $\mathrm{C}_{4} \mathrm{AF}$ in large proportions when compared to the CEM II/B mortars. These results confirmed earlier findings that the presence of $\mathrm{C}_{3} \mathrm{~A}$ is not the only cause of expansion due to sulfate attack (Cao et al. 1997; Tangchirapat et al. 2009).

According to ACI Committee 201 (1991) ettringite formation derived from ferroaluminate phase has also been assumed as a potential sulfate deterioration problem. The improvement of sulfate resistance by adding scoria as cement replacement can be mainly explained by the pore size refinement, the removal of lime by the pozzolanic reaction of scoria with the lime liberated during cement hydration and the $\mathrm{C}_{3} \mathrm{~A}$ dilution (Irassar et al. 2000; Hooton and Emery 1990; al-Amoudi 2002; Al-Dulaijan et al. 2003). The pore size refinement reduced the permeability of the paste, thus limiting the ingress of sulfate ions (Irassar et al. 2000). In terms of cement composition, $\mathrm{C}_{3} \mathrm{~A}$ is the main compound involving sulfate resistance, whereas $\mathrm{C}_{4} \mathrm{AF}$, an alumina bearing phase, and $\mathrm{CH}$ released from silicates hydration can also affect the sulfate resistance of low $\mathrm{C}_{3} \mathrm{~A}$ Portland cements (Gonzalez and Irassar 1997). On the other hand, the $\mathrm{C}_{3} \mathrm{~S}$ content was considered an important parameter on sulfate resistance of PC, too (Irassar et al. 2000). It can be noted that for CEM I of about $6 \% \mathrm{C}_{3} \mathrm{~A}$ content, blending with $25 \%$ scoria content or more usually resulted in a performance similar to that of SRPC. This result is similar to that reported by Lawrence (1990).

\section{Conclusion}

From the experimental results, the following conclusions could be drawn:

- The studied scoria is a suitable material for use as a natural pozzolan. It satisfied the ASTM \& EN requirements for such a material. The physical properties of binders containing scoria are also in conformity with the standards requirements.

- The compressive strength of concrete containing scoriabased binders was lower than that of plain cement concrete at all ages of concrete in this study. At early ages, the concrete containing CEM II/B-P binder types had compressive strengths much lower than that of plain cement concrete. However, at 90 days curing, the compressive strengths of blended cement concretes are comparable to those of plain cement concrete.

- The chloride penetrability of scoria-based concrete mixes is much lower than that of plain concrete, especially at high replacement levels of scoria.

- According to the results of accelerated corrosion test, concretes produced with scoria-based binders decelerated rebar corrosion. Particularly, CEM II/B-P binder types with 25,30 and $35 \%$ scoria content were found to delay corrosion significantly. Use of scoria at $30 \%$ cement replacement level delayed significantly initial corrosion times under chloride-bearing environments.

- Based on the results, blending CEM I of $6 \% \mathrm{C}_{3} \mathrm{~A}$ content, with $25 \%$ scoria content or more resulted in a performance similar to that of SRPC and an enhanced acid resistance, as well.

- Adding scoria as cement replacement reduced the expansion of the mortar bars exposed to sodium sulfate solution. More reduction occurs with increasing the replacement level.

- Blended cement concretes have lower compressive strengths, but greater resistance to chloride penetration, longer corrosion initiation times, greater resistance to acid attack and lower expansion in sodium sulfate solution compared with plain cement concretes after 28 and 90 days curing. So, it would be erroneous to predict durability based on strength.

- Based on the results obtained, it is suggested that scoria can be used up to $30 \%$ as a partial substitute for PC in production of blended cements. This addition ratio can reduce the quantity of $\mathrm{CO}_{2}$ released by Syrian cement plants, and the consumed energy. So, production of a green concrete could be promoted.

\section{Acknowledgments}

The authors gratefully acknowledge the technical and financial support of this research from the management of General Organization for cement and Building Materials/Adra Cement Plant. Thanks are also expressed to Chemist Nazeer Adarnaly, Eng. Amjad Bernieh (Lafarge Co.) and Prof. Tamer al-Hajeh, vice-president of AIU for their appreciated help.

\section{Open Access}

This article is distributed under the terms of the Creative Commons Attribution 4.0 International License (http:// creativecommons.org/licenses/by/4.0/), which permits unrestricted use, distribution, and reproduction in any medium, provided you give appropriate credit to the original author(s) and the source, provide a link to the Creative Commons license, and indicate if changes were made. 


\section{References}

ACI Committee 201. (1991). Guide to durable concrete. ACI Materials Journal, 88, 551-554.

al-Amoudi, O. S. B. (2002). Attack on plain and blended cements exposed to aggressive sulfate environments. Cement \& Concrete Composites, 24, 304-316.

Al-Chaar, G. K., Al-Kadi, M., \& Asteris, P. G. (2013). Natural pozzolan as a partial substitute for cement in concrete. The Open Construction and Technology Journal, 7, 33-42.

Al-Dulaijan, S. U., Maslehuddin, M., Al-Zahrani, M. M., Sharif, A. M., Shameem, M., \& Ibrahim, M. (2003). Sulfate resistance of plain and blended cements exposed to varying concentrations of sodium sulfate. Cement \& Concrete Composites, 25, 429-437.

Al-Tayyib, A. J., \& Al-Zahrani, M. M. (1990). Corrosion of steel reinforcement in polypropylene fiber reinforced concrete structures. ACI Materials Journal, 87(2), 108-113.

ASTM C1012 (2004). Standard test method for length change of hydraulic-cement mortars exposed to a sulfate solution. West Conshohocken, PA: ASTM International.

ASTM C1202 (2001). Electrical indication of concrete's ability to resist chloride ion penetration. West Conshohocken, PA: ASTM International.

ASTM C267 (2001). Standard test methods for chemical resistance of mortars, grouts, and monolithic surfacings and polymer concretes. West Conshohocken, PA: ASTM International.

ASTM C618 (2001). Standard test methods for coal ash and raw or calcined natural pozzolan for use as a mineral admixture in concrete. West Conshohocken, PA: ASTM International.

ASTM C595 (2001). Standard specification for blended hydraulic cements. West Conshohocken, PA: ASTM International.

Aydın, S., Yazıcı, H., Yigiter, H., \& Baradan, B. (2007). Sulfuric acid resistance of high-volume fly ash concrete. Building and Environment, 24, 717-721.

Cao, H. T., Bucea, I., Ray, A., \& Yozghatlian, S. (1997). The effect of cement composition and $\mathrm{pH}$ of environment on sulfate resistance of Portland cements and blended cements. Cement \& Concrete Composites, 19(2), 161-171.

Cavdar, A., \& Yetgin, S. (2007). Availability of tuffs from northeast of Turkey as natural pozzolans on cement, some chemical and mechanical relationships. Construction and Building Materials, 21, 2066-2071.

Chindaprasirt, P., Chotithanorm, C., Cao, H. T., \& Sirivivatnanon, V. (2007). Influence of fly ash fineness on the chloride penetration of concrete. Construction and Building Materials, 21, 356-361.

Colak, A. (2003). Characteristics of pastes from a Portland cement containing different amounts of natural pozzolan. Cement and Concrete Research, 33, 585-593.

EN 196-2 (1989). Methods of testing cement, part 2. Chemical analysis of cement. Brussels, Belgium: European Committee for Standardization.

EN 197-1 (2004). Cement: part 1. Composition, specification and conformity criteria for common cements. Brussels, Belgium: European Committee for Standardization.
Fattuhi, N. I., \& Hughes, B. P. (1988). SRPC and modified concretes subjected to severe sulphuric acid attack. Magazine of Concrete Research, 40, 159-166.

Gastaldini, A. L. G., Isaia, G. C., Gomes, N. S., \& Sperb, J. E. K. (2007). Chloride penetration and carbonation in concrete with rice husk ash and chemical activators. $\mathrm{Ce}$ ment \& Concrete Composites, 21, 356-361.

Ghrici, M., Kenai, S., \& Meziane, E. (2006). Mechanical and durability properties of cement mortar with Algerian natural pozzolana. Journal of Material Science, 41, 69656972.

Gonzalez, M. A., \& Irassar, E. F. (1997). Ettringite formation in low C3A Portland cement exposed to sodium sulfate solution. Cement and Concrete Research, 27(7), 1061-1072.

Guneyisi, E., Ozturan, T., \& Gesoglu, M. (2005). A study on reinforcement corrosion and related properties of plain and blended cement concretes under different curing conditions. Cement \& Concrete Composites, 27, 449-461.

Ha, T., Muralidharan, S., Bae, J., Ha, Y., Lee, H., Park, K., \& Kim, D. (2007). Accelerated short-term techniques to evaluate the corrosion performance of steel in fly ash blended concrete. Building and Environment, 42, 78-85.

Hooton, R. D., \& Emery, J. J. (1990). Sulphate resistance of a Canadian slag cement. ACI Materials Journal, 87(6), 547555.

Horsakulthai, V., Phiuvanna, S., \& Kaenbud, W. (2011). Investigation on the corrosion resistance of bagasse-rice husk-wood ash blended cement concrete by impressed voltage. Construction and Building Materials, 25, 54-60.

Hossain, K. M. A. (2003). Blended cement using volcanic ash and pumice. Cement and Concrete Research, 33, 1601-1605.

Hossain, K. M. A. (2009). Resistance of scoria-based blended cement concrete against deterioration and corrosion in mixed sulfate environment. Journal of Materials in Civil Engineering ASCE, 21(7), 299-308.

Hossain, A. B., Shirazi, S. A., Persum, J., Neithalath, N. (2008). Properties of concrete containing vitreous calcium aluminosilicate pozzolan. In Proceedings of the 87th transportation research board annual meeting, January, Washington DC.

Irassar, E. F., Gonzalez, M. A., \& Rahhal, V. (2000). Sulfate resistance of type $\mathrm{V}$ cements with limestone filler and natural pozzolan. Cement \& Concrete Composites, 22(5), 361-368.

ISO 4012 (1978). Concrete: Determination of compressive strength of test specimens. London, UK: ISO.

Khedr, S. A., \& Idriss, A. F. (1995). Resistance of silica-fume concrete to corrosion-related damage. ASCE, Journal of Materials in Civil Engineering, 7(2), 102-107.

Lawrence, C. D. (1990). Sulfate attack on concrete. Magazine of concrete Research, 42(153), 249-264.

Mehta, P. K., \& Monteiro, P. J. M. (2006). Concrete: Microstructure, properties, and materials (3rd ed.). New York, NY: McGraw-Hill, ISBN 0-07-146289-9.

Mindess, S., Young, J. F., \& Darwin, D. (2003). Concrete (2nd ed.). Upper Saddle River, NJ: Prentice Hall. 
Montgomery, D. C., \& Peck, E. A. (1982). Introduction to linear regression analysis. New York, NY: Wiley.

Neville, A. M. (2011). Properties of concrete (5th ed.). London, UK: Pearson Education.

Parande, A. K., Babu, B. R., Karthic, M. A., Deepak Kumaar, K. K., \& Palaniswamy, N. (2008). Study on strength and corrosion performance for steel embedded in metakaolin blended concrete/mortar. Construction and Building Materials, 22, 127-134.

Pavlik, V. (1994). Corrosion of hardened cement paste by acetic and nitric acids; Part II: Formation and chemical composition of the corrosion products layer. Cement and Concrete Research, 24, 1495-1508.

Pourkhorshidi, A. R., Najimi, M., Parhizkar, T., Jafarpour, F., \& Hillemeier, B. (2010). Applicability of the standard specification of ASTM C 618 for evaluation of natural pozzolans. Cement \& Concrete Composites, 32, 794-800.

Ramezanianpour, A. A., Mirvalad, S. S., Aramun, E., Peidayesh, M. (2010). Effect of four Iranian natural pozzolans on concrete durability against chloride penetration and sulfate attack. In P. Claisse et al. (Ed.), Proceedings of the 2nd international conference on sustainable construction materials and technology, 28-30 June, Ancona, Italy.

Reddy, D. V., Edouard, J. B., Sobhan, K., Rajpathak, S.S. (2011). Durability of reinforced fly ash-based geopolymer concrete in the marine environment. In Proceedings of the 36 th Conference on Our World in Concrete \& Structures, August 14-16, Singapore.

Rodriguez-Camacho, R. E., \& Uribe-Afif, R. (2002). Importance of using natural pozzolans on concrete durability. Cement and Concrete Research, 32, 1851-1858.

Rossignolo, J. A., \& Agesini, M. V. C. (2004). Durability of polymer-modified lightweight aggregate concrete. Cement \& Concrete Composites, 26(4), 357-380.

Rukzon, S., \& Chindaprasirt, P. (2009). Effect of grinding on chemical and physical properties of rice husk ash. Int $J$ Miner Metal Mater, 16(2), 242-247.
Saraswathy, V., \& Song, H.-W. (2007). Corrosion performance of rice husk ash blended concrete. Construction and Building Materials, 21, 1779-1784.

Senhadji, Y., Escadeillas, G., Khelafi, H., Mouli, M., \& Benosman, A. S. (2012). Evaluation of natural pozzolan for use as supplementary cementitious material. European Journal of Environmental and Civil Engineering, 16(1), 77-96.

Shaker, F. A., El-Dieb, A. S., \& Reda, M. M. (1997). Durability of styrene-bautadiene latex modified concrete. Cement and Concrete Research, 27(5), 7711-7720.

Talbot, C., Pigeon, M., Maarchand, M., \& Hornain, J. (1995). Properties of mortar mixtures containing high amounts of various supplementary cementitious materials. In $\mathrm{V}$. M. Malhotra (Ed.), Proceeding of the fifth international conference on the use offly ash, silica fume, slag, and natural pozzolana in Concrete, ACI SP 153, Milwaukee (pp. 125-152). Milwaukee, WI: American Concrete Institute.

Tangchirapat, W., Jaturapitakkul, C., \& Chindaprasirt, P. (2009). Use of palm oil fuel ash as a supplementary cementitious material for producing high-strength concrete. Construction and Building Materials, 23(7), 2641-2646.

The General Establishemnt of Geology and Mineral Resources in Syria. (GEGMR). (2007). Official document no. (3207/ T/9), dated 21.11.2007 (in Arabic).

The General Organisation for Cement \& Building Materials. (GOCBM) (2011). www.cemsyria.com. Accessed 2011 (in Arabic).

The General Establishment of Geology and Mineral Resources in Syria (GEGMR). (2011). A Guide for mineral resources in Syria (in Arabic).

Turanli, L., Uzal, B., \& Bektas, F. (2005). Effect of large amounts of natural pozzolan addition on properties of blended cements. Cement Concrete Research, 35(6), 11061111. 